\title{
Introduction: Strangers and Aliens in London ca 1605 - Is Anyone Stranger than a London Gallant?
}

\begin{abstract}
This special issue on John Marston's The Dutch Courtesan illustrates the various tensions in London at the start of James I's reign. This city comedy deploys satire to urge its audience to see the anxiety and fears caused by misogyny, xenophobia, religious dissent, and contact with European foreigners, all of which create an alien environment infecting those who live in it. Each of the ten essays that make up the issue touches on these anxieties, or at least elements of strangeness that need arguing away or accepting as unresolvable in Marston's view of human nature.
\end{abstract}

Like John Marston himself — son of a lawyer, law-student at the Middle Temple, satirical poet, and experimenter with revenge plays, ultimately and abruptly a country parson breaking all ties with theatre - this special issue on The Dutch Courtesan (1605) offers something surprising and new. Its goal is to illustrate how the play-text, both in the form of an early printed book and a modern edition, can inspire performances sustaining multiple reactions and points of view, which the bodies of actors communicate to the receptive audience. Often unexpected actions, gestures, facial expressions, and sounds produced by actors and musicians give significance to staged verbal silences based on absences in the text. We can only speculate on the bodies of the boy actors who presented Marston to his audience, but we can, if we are lucky, see modern productions that bring us closer to understanding Marston's theatrical world. ${ }^{1}$ Even Edward's Boys, the company of schoolboys at King Edward VI's School in Stratford-upon-Avon, superb as they are, will never replicate a 400-year-old theatrical interpretation as it was performed in Blackfriars: the space, the neighbourhood, the atmosphere, and the physical bodies of audiences and actors cannot be the same. ${ }^{2}$ The authors in this issue examine both the play's original context and its modern resonances to

Helen Ostovich (ostovich@mcmaster.ca) is professor emerita of English and Cultural Studies, McMaster University, and now editor emerita of this journal, Early Theatre, which she founded in 1998. 
explore otherness, gender, sex, religion, and foreignness. They also discover ways in which actorly and scholarly ways of knowing extend and enrich each other.

Marston's London was cosmopolitan ${ }^{3}$ and deeply anxious about the place of 'strangers' within its urban landscape, and the play's plots push both factors to dizzying complications. The main plot deals with the treatment of a foreign sex worker whose accent helps establish her otherness; the counterplot ${ }^{4}$ follows two members of a distrusted religious minority as they are tricked and abused, presumably for the audience's entertainment. This double plot line understood as the superficial context, we reconsider The Dutch Courtesan based on the production at the University of Toronto during the week of 19-24 March 2019, and the symposium on 22 and 23 March partnering that production. ${ }^{5}$ The symposium speakers whose work is published here have revised their papers in light of what they learned about the play in performance and its impact on their theories, having been confronted by both practice and collegial discussion. The key observation that emerges concerns how London accommodated the foreign: suspiciously, looking askance at its own citizens as much as at aliens. Xenophobia aroused wide-spread hostility, with fears that a surge of 'strange' persons, languages, diseases, or customs from some other country or neighbourhood might adulterate or somehow substantially infect 'pure' English habits. ${ }^{6}$ That notion activates Freevill's caprices in the play, but he is not alone. Such qualms become tangled with related misogynistic fears among the play's men, particularly fear of sex workers. Bizarrely, those workers include wives and daughters, when husbands and fathers feel the need to sequester chaste women from learning about the power women can exert over men. Marston brings these fears together in The Dutch Courtesan.

This introduction attempts to find a path among the essays collected here, to enhance the accomplishments of the authors by putting them into virtual conversation with one another, beginning with an analysis of the text of Marston's play and its place in Jacobean printed drama as our 'deep background' for studying The Dutch Courtesan, and then grouping the remaining nine essays in clusters of three, moving from text to performance. Productions of this Marston play are rare on the professional stage, thus reducing our access to and understanding of the kind of entertainment it offers, but I will give an extended example from the Edward's Boys Archive of how I came to a richer understanding of the FreevillMalheureux relationship by reading what Owen Hibberd (Malheureux) had to say about rehearsing and performing his part in 2008:

From the meaning of the name I ... believe[d] that the character was ... a weaker personality than Freevill, but much prefer the idea of 'eyebrow' [that is, responding 
ironically], of Malheureux also being a strong personality, and of playful banter between Freevill and Malheureux.

Owen then recounted his summer experience working in the City - the part of London inside the walls, primarily concerned with issues of commerce, law, and government — on the trade floor of a bank:

The majority of people who worked in the City seemed to be men, and the whole place worked in a very 'male' way, in the sense there was an extremely competitive air about, everybody was trying to get 'one over' on each other, they were constantly throwing out sexual innuendos, verbally but jokingly attacking each other, and at one point some guys went around the room (massive trade floor) planting a remote controlled fart box under unsuspecting victims' chairs - which received wails of laughter from the men I was with. I see SO much of this behaviour in The Dutch Courtesan, especially between Freevill and Malheureux: absolute male 'banter'. At the beginning of the play when Freevill is convincing Malheureux to come with him to the brothel they are verbally attacking each other just like these 'City boys' on the trade floor - hilarious, dirty and intellectual word play. And also, most probably just like these City boys, they go out in the evening, spend lavish amounts of money on fine food and wine, and then find some woman to shag.

This theory works, or is workable, in the play, giving us a Malheureux who is both (a) 'knowing' about sex, raising a brow at Freevill's appraisals of life, crime, and trade, and (b) 'unknowing' about how far a youth might go with a prostitute. Malheureux seems less a novice and more a doubting Thomas in face of Freevill's 'performance' as a worldly-wise man-about-town.

Such working out of potential meaning for performance begins with the playtext, and the first essay in this collection, Martin Butler's 'The Oxford Marston and The Dutch Courtesan', sets the context for this issue, and indeed for the whole Marston project, by considering the relationship between text and performance. Butler explains the rationale for the new Oxford Works of John Marston (in progress): the need for a modern text, the first complete critical edition of all the plays, poetry, and other documents pertaining to Marston's life, the print history, and, importantly, the theatre history. Text, when we speak of a playwright, precedes performance, although clearly Marston was influenced by the playwrights who preceded him, the actors he wrote for, and the performances that surprised or aroused his own experiments with the stage. Simply put, the text takes on fuller meaning when the actors make the text physically present, seen and heard. 
Butler discusses some of the unusual print features of Marston quartos that might enhance or suggest performance, such as the numerous epigrams and sententiae set off by italics, some of which were familiar proverbs and some apparently invented. He gives us a graphic view of how a reader 'talks back' to the text through annotation; and illuminates Marston's negative approach to play publication: he wrote his plays for performance, not for print. The essays that follow reveal the conditions and impacts of performance in order to better understand the theatrical possibilities and conceptual implications of the Marston text.

In taking up Marston's play, therefore, we have to keep in the forefront of our minds that his text records potential for performance, and seeds and snippets of other performances, because Marston has his characters converse with and about ideas in books (for example, Montaigne) and demonstrate theatrical ideas (in plays by Shakespeare, Jonson, and others) gleaned from observation as an audience member. Marston was innovative in his approach to dramatic structure and balance, and as a result his work sometimes can seem off-kilter or chaotic (on this point see Michael Cordner's essay in this issue). If we understand Marston's strategy as deliberate, we have to rethink what his plays mean and how audiences, then and now, might respond.

The three essays following Butler's consider the 'Foreign Inf[1]exions' expanding (or some would say contaminating) English commerce, theatre, and religion in the mixed culture of London at the beginning of James I's reign: specifically, foreign theatre (Tom Bishop), foreign religion (Sophie Tomlinson), and foreign disease (Andrew Fleck). In "La bella Franceschina" and Other Foreign Names in Marston's The Dutch Courtesan', Bishop relates the history and impact of commedia dell'arte on the English stage, especially in the figure of Franceschina, whose name has a pan-European connection with saucy maids and sexually knowing women. Marston's Franceschina, however, is not alone in her Italian naming: Crispinella and Beatrice, nurtured by Putifer, form an Italianate group combining the practical (St Crispin, the patron of shoemakers, curer of soles/ souls) with the poetic (Dante's ideal woman), in young women intelligently conversing and questioning literary and cultural ideas, tended by a governess who has taught her nurselings how to think and evaluate (puto, Latin). On the other hand, Franceschina is Dutch, and her language is as various as her previous lovers and her transnational theatrical representations as a commedia character. In London streets and in city comedy, foreign accents and dialects were comic class markers, implicit put-downs of alien characters; London attitudes towards such sounds and mannerisms explain why Freevill and Cocledemoy both assume accents in their 
disguises (French, Welsh, Scottish, Dutch, Italian), because native Londoners can shrug off foreigners disdainfully as invisible or unimportant.

Both Tomlinson and Fleck talk about how Dutch infiltration can have serious consequences socially, commercially, and culturally. Theatrically speaking, Franceschina, as the play's prime representation of foreign invasion, is not a first for the London stage. Robert Wilson's The Three Ladies of London (1582; rev. 1594), an earlier dystopian comedy of pollution, shows us an even darker London organized by the crime boss Lady Lucre (born Italian), who co-opts men to do her dirty work, spreading disease, theft, eviction, and murder, while she enjoys seducing the properly English Lady Love and Lady Conscience into her 'family of love' where brothels, trade, church, and politics mingle. Like Marston's Franceschina, performance itself, seductive and hypocritical, becomes a polluting import with its comic love-triangles, disguises, revenges, pan-European popular song, and the disruptive cosmopolitanism of overseas mercantile or commercial ventures destroying honest English businesses. ${ }^{8}$

Among other factors intervening in English life (status of gender, class, trade, or religion), the Dutch sect, the Family of Love, plays a defining role in The Dutch Courtesan's fictional world. In 'Sensuality, Spirit, and Society in The Dutch Courtesan and Lording Barry's The Family of Love', Sophie Tomlinson discusses two different theatrical representations of Familism, Marston's (1605), particularly in the Mulligrub plot, and Barry's (1608), the latter virtually 'in dialogue' (p. 71) with the earlier play, and probably written much closer in time to Marston's first performance and subsequent printing of The Dutch Courtesan. Tomlinson points out a significant difference between the incidental presence of Familism in Marston's play, as the background to the crushing hypocrisy that exists at all levels of the London community, and the direct focus on Familism in Barry's play, echoing and expanding Marston's comedy into a lighter farce about free love and women's freedom to choose - this last, of course, also Crispinella's purpose and Mistress Mulligrub's practice. Both plays trace women's behaviour by following their rings as symbols of containment within legal or illicit arrangements. Although Franceschina thinks that possession of Beatrice's ring will free the rejected courtesan of her desire for revenge, she (Franceschina) is the one who ends up contained in prison because of it. The staged circulation of rings ends abruptly in both plays, but the ring in Marston's Dutch Courtesan seems to follow the magical journey of the exotic handkerchief in Othello, from Egypt to Italy, from Othello to Desdemona, from Emilia to Iago, from Bianca to Cassio, gradually getting sullied in the process, and eventually abandoned in the street. The physical object symbolically tracks the devaluation of everyone who touches it. In Marston, although the ring 
may return to the right hand, it too confirms devaluation, alongside the women's isolation and commodification within marriage, calling into question the worth of the husband who consigns them to such a bond. (See Meghan Andrews's essay, in this special issue, on the exchange of rings). In Barry, the ring confirms marriage vows, and paradoxically allows for a woman's freedom to love - to love anyone God gave life to. In the words of Marston's 'Fabulae argumentum', both plays claim to distinguish the love of a courtesan and a wife, but the terminology gets twisted into morally ambiguous arguments about values, trust, and faith, calling into question the easy distinction between the morality of English sacred institutions and foreign religious practice, defying the black-and-white simplicity of the original storyline.

Familism conflicted not only with the Church of England, but also with other dissenting or puritan sects. In 'Proximity and the Pox: Pathologizing Infidelity in Marston's The Dutch Courtesan', Andrew Fleck connects syphilis and heterodoxy through the play's emphasis on the Family of Love: Familists often kept their faith secret (for purposes of subversion, as orthodox Christians commonly thought), or seemed to comply with the majority faith (and thus popular writings often accused Familists of hypocrisy), in order to secure their occupations and stimulate increase in the trades or professions. As a result, the sect seemed to be an infection, invisibly destabilizing the English establishment, just as Franceschina, a strange woman, corrupts those who desire her. But the strangeness she represents was already current in London immigration and trade, forcing audiences to account for their reception of actions that seem distorted and defamiliarized in the city setting, recognizing and not recognizing themselves in the play's funhouse mirror, and, as Erin Julian remarks later in this issue, laughing inappropriately at what they cannot deal with. The uncomfortable ambiance renders dramatic action hostile, repugnant to families, communities, or faiths. Nothing is safe.

Fleck gets right to the heart of the contagions unsettling London's status quo. His historical survey of venereal disease latches onto Franceschina as the pernicious foreign agent of corruption, seducing and infecting the City in a mercantile pattern traced with different emphasis by Liz Fox later in this issue. Fleck shows us the disease infesting alehouses and brothels, seeping into private spaces, and then infecting everyone from infants to seniors. This pandemic blights Christian morality with challenges that could overturn the Church of England itself. Threatening with apocalyptic rhetoric, her brothel the heart of sedition, her broken English the harbinger of England's fate, Francheschina, as Fleck notes in an earlier version of his essay 'the Whore of Babylon in Anglo-Dutch form'. Her infection of religion is the last stage of depravity corrupting family, law, and commerce with what 
amounts to viral contamination. The history of the Family of Love, hand in hand with the history of venereal disease in Europe, links Marston's play to the anxieties in England: the fear of multiplying infections that destroy body and soul, a dark conspiracy that explains the complications in these 'Foreign Inf[1]ections', and sets us up to read the next three essays.

The common theme for this second triad of papers is 'Commodification and Seduction': together, these essays examine the relationship between theatrical space and commercial enterprise, seeing the commodification of boys and women within a system of seduction (by the seller, whether tradesman or actor or character) in order to build capital. In 'Living by Others' Pleasure: Marston, The Dutch Courtesan, and Theatrical Profit', Lucy Munro discusses aesthetics and moneymaking in relation to the Children of the Royal Chapel and the music crucial to their plays. New documentary evidence on the circumstances of the choir both as spiritual support in the Queen's Chapel and as entertainment (in the form of acting and singing) for paying customers in the theatre, establishes for the first time the importance of keeping the boys attached to both, despite legal disputes raised by the Clifton affair. The legitimacy offered by the chapel choir places the pleasure of hearing the boys' voices beside the commercial profit they accumulate in their theatre work. With a foot in both worlds - profit for the spirit, profit for the theatrical company, both offering pleasure for ears, eyes, and minds - the boys were able to merge two hitherto mutually exclusive properties into the renamed Children of the Queen's Revels. The business side, formerly seen as infecting viewers with sinful behaviour and ideas, became acceptable when the theatrical music now exculpated and heightened audience pleasure endorsed by the prestige of royal and church patronage. Marston's play, nevertheless, still seems uneasy with this convergence, if, as Munro argues, music becomes a way of questioning the sincerity of Freevill and other seducers.

In 'How Marston Read his Merchant: Ruled Women and Structures of Circulation in The Dutch Courtesan', Meghan Andrews identifies potent source material for Marston's play in Shakespeare's Merchant of Venice, a play sharply critical of the commodification of minds and bodies, and the hollowness of a young man's choice between 'purse and person', in this author's wryly witty assessment. Both Shakespeare and Marston critique male sexuality, with Bassanio trying to be a romance-narrative hero and Freevill failing completely at the role. Instead Freevill reveals his performance as 'inauthentic', completely misinterpreting Beatrice's Patient Griselda, a performance she may grow out of by act 5 scene 3. Before that, she does all the suffering, and he escapes feeling anything by successfully blaming Franceschina for all wrongs. Whereas Merchant shows the transition of Bassanio 
from fashionable gallant commodifying others and marrying wealth, to kept husband ruled by a strong Portia (herself no slouch at commodifying and scapegoating others), Freevill demonstrates the complete cynicism of the commodifying male: mercenary, manipulative, interested only in his own financial and social security. He marries a virgin who won't know her husband's cruel nature until it's too late, despite her close questioning of his absence and activities. The ring plot in each play gives the female protagonist opportunity to expose her false lover, but only Portia seizes the advantage. In that sense, she is the true mother of Freevill: her spouse-testing, like his, depends on disguise and deceit, finally blaming the other (Shylock) for all the commercial, social, and moral problems of the play. So too, Freevill blames Franceschina and wins Beatrice, the golden prize - even though, as Tomlinson recalls, Carmen Kruk's Beatrice raised an eyebrow at Freevill's 'performance' in the 2019 Toronto production, just like Owen Hibberd's Malheureux in 2008.

Liz Fox addresses commodification in acts of salesmanship like those suggested in the old proverb, 'Things farre fet and deere bought are good for Ladyes', in her essay 'Cosmopolitan Desire and Profitable Performance in The Dutch Courtesan'. The salesman dazzles the customer with exotic products, the customer's desire causes loss of judgment, and the salesman's performance wins the profit: seducing the customer causes a 'conversion' from initial indifference or mild curiosity to raging lust for whatever is on offer. In brief, this summary is not far off the boys company's use of music to draw in patrons (Munro), or Freevill's and Portia's performances at home and abroad to achieve their own ends (Andrews). This paradoxical transformation of sense not only provokes a material commercial transaction but also simulates religious conversion, which, Fox ponders, may have more of a sexual dimension than hitherto thought. Certainly the Family of Love, according to Marston's sect-members, meet for sexual sharing of 'God', combining the spiritual and physical. The salesman-seducer, however, does not convert: Franceschina uses her Dutch accent and European sex appeal to market herself as a foreign luxury, desired first by Freevill, then Malheureux, and coincidentally Cocledemoy - although Cocledemoy is also a salesman, using foreign accents, misleading costumes, and seductive manner to persuade or convert his audiences to his use. In these cases, the seducer balances the potential risk of action against the profits of seduction. Cocledemoy lets the audience into the secrets of his exploitation of others, thus making spectators complicit in his tricks; so too Franceschina amazes her audiences with sinuous song and dance, seducing with her foreign wares, and converting good English capital into bad foreign deals. The offstage audience, the final target of these seductions, encourages the characters/ 
players' ${ }^{9}$ outrageous trickery, a fact of theatrical pleasure that kept the Children of the Queen's Revels a successful money-maker.

The final three essays fall under the rubric of 'Learning from Rehearsal and Production', with authors focusing on the 2013 performance at the University of York and the 2019 production at the University of Toronto, especially what they learned about potential for action and character. In 'The Dutch Courtesan and "The Soul of Lively Action"', Michael Cordner focuses on what characters do and say - 'lively action' (the 'performed facts' of the plot) being the most important dynamic, according to Aristotle's experience as a spectator in the theatre. Performance embodies the many ways to play relationships like the triangle of Freevill, Franceschina, and Malheureux, because actors and spectators alike have to listen to see what is at stake, especially for those characters more or less at the margins of early modern life: women, foreigners, dissenters. The real meaning of a plot emerges if we ask questions about choices and silences in the text, where knowledge we thought we had earlier seems to erode; for example, we cannot know that Beatrice will marry Freevill at the end of act 5, when she has no lines and Freevill stops speaking mid-scene, after the rescue of Malheureux — but Tisefew does ask his future father-in-law for Crispinella's hand. Cordner argues effectively that the 'passionate man' in the Prologue does not refer to Malheureux, but to all the characters who experience extremes and contradictions, and then have to rethink the ethics of suicide, deceit, betrayal, false report of death, promises of love, vows of vengeance, and objections to libertine excess. What should we think of a jeerer who mocks principles we know to be valid? Freevill's clever arguments throughout the play show skills dedicated solely to promoting his own self-interest and self-display, like the schoolboy public-speaking competitions at Bartholomew Fair, or the moots at the inns of court. We don't see evidence of something akin to Malheureux's self-analysis, Beatrice's sincere questions, or Crispinella's clear responses to social inequities — or Mulligrub's decency — in anything Freevill says. Marston's plot is not about London's polarized worlds of class, gender, national origin, or personal income, but about overlapping experiences, seen and heard in complicated performances that provoke rich responsiveness on and off the stage, interactions that are ultimately unresolved.

Erin Julian, in "Our hurtless mirth": What's funny about The Dutch Courtesan?', gives similar attention to the complexities of comedy, but focuses more on representations of gender. The early modern world, like ours, was full of anxiety and danger, caused by general xenophobia and fear of change, whether at home, in the city, or in innovations imported from another country - like forks, used in Italy and France well before they arrived in England, or religious practices from 
the Netherlands seeping into England. Such a society meets confrontations with hostility, separating into in-groups and out-groups, whether among gentlemen, between gentlemen and tradesmen, or between men and women. The basis of the city comedy they enact is humiliation of one before the others, scapegoating to confirm an established pecking order. And what's funny to the in-group is not so funny to the out-group. In his mock-sympathy for Mulligrub's loss in the opening scene, Freevill establishes himself as the kingpin in male/male relations, the master storyteller enjoying the humiliation of the tavern owner while seeming to console him. Crispinella enjoys spiteful storytelling too, and in male/female relations shows herself top dog: Caqueteur suffers humiliation when she teases him and then lets Tisefew attack him physically and verbally. Only in the context of female relations is the bite lessened: the sisters mock their roles as sex objects, but when something serious emerges, like Beatrice's collapse at Freevill's 'death' and sudden 'rebirth', Crispinella sides with her sister in flatly rebuking Freevill as a wrong-doer. Much of the comedy is hurtful, not 'hurtless', compounded by lies, masquerades, and brutality that lead to the gallows. Cocledemoy desensitizes the audience with his cat-and-mouse games, to make sure the audience directs laughter unsympathetically at the mice. When Beatrice experiences the game, she cannot laugh, but inadvertently censures the culprit, perhaps most comically in act 4 scene 4, where she unthinkingly reverses the pain of her loss of Freevill onto Franceschina. The male relationships provoke the most laughter through a potent combination of tricksters, dupes, and audiences: the liars who break the weakest link escape blame.

Like Julian, Noam Lior also discovers the hurtful mirth of Marston's comedy through his analysis of the play in rehearsal and performance, in "Unwholesome Reversions": Contagion as Dramaturgy in The Dutch Courtesan'. Scenes, characters, and events alter their meaning by propinquity. At the same time the sequence gives the spectators means by which to reassess and reject xenophobia and gender violence by recognizing these problems in repeated patterns. When a positive model of social or economic relationship becomes contaminated by a negative model, the audience sees the consequences of intolerance and complete lack of compassion. They may also lack the intelligence to see the impact of bad behaviour on both models, when an unjustly injured party accepts suffering inflicted by the self-serving arguments of self-styled moralists like Freevill and Cocledemoy. The circulation of Beatrice's ring shows how a positive model can be progressively contaminated - as I suggest on page 15 above, regarding Othello, and as Andrews argues in her essay, pages especially 130-5. Franceschina herself represents the 'human cost' of foreign and sexual commerce, just as Mulligrub 
becomes the scapegoat for his outsider status, even though the worst offenders are the xenophobic intolerant tricksters who spread their evil when it need not have existed at all. The reason? The social education that allows Englishmen to perform acts of intolerance and xenophobia also keeps them blind to the pain others experience. As Owen Hibberd says, it's just 'male banter'. Freevill's conversion is shallow, as is Cocledemoy's unrepentant self-justification. Only the self-aware are hurt and then silenced: Malheureux, Beatrice, Mulligrub, and Franceschina. As Cordner suggests, the play ends oddly in medias res.

Marston's text is challenging, and so is the performance of its dialogue and silences, its material staging, and its actorly interpretation of meaning. These theatrical elements work most valuably when they unsettle an audience's certainty about the urban values we live by. The contributors to this issue open up areas of new interest in The Dutch Courtesan by concentrating on Marston's attacks on urban corruption. What I have found most persuasive is the consensus among all the authors not to locate the moral centre of the play in Freevill, the gallant among gallants, none of whom show us much to admire. ${ }^{10}$ How does Marston dispose of his 'hero' and why does he balance Freevill's plots with Cocledemoy's practical jokes? If the fool wins the contest by taking over audience attention, framing both Mulligrub's near-hanging and the play's epilogue, how much weight do we give the problem of alienated, frivolous, and manipulating London gallants? ${ }^{11}$ Altogether, this special issue's contents offer a fresh and complicated awareness of what it means to be part of Marston's appallingly funny appraisal of humankind. In the essays, The Dutch Courtesan seems constantly to reinscribe the play's words and events with ourselves as audience and hapless victims, our intellectual, emotional, and physical awareness of social injustices reshaped as the embodied city comedy makes us see it. Much as we try to avoid it, we find ourselves at the heart of what is strange and alienating in Marston's world, including our own laughter. 


\section{Notes}

Many thanks to Erin Julian for assisting with first drafts of essays, and to Melinda Gough and Erin Kelly for improvements to this introduction.

1 Consider, for example, David Crane's impish suggestion that Marston decided to cast the prettiest boy in the Children of the Revels as a whore who consciously plays on relations between audience and stage, going beyond the role's demands to bewitch and critique 'what is on offer and at issue': schoolboys in the vicinity of commercial London with onlookers very much aware (on both sides) of the 'market' that lures them into the theatre. See 'Patterns of Audience Involvement at the Blackfriars Theatre in the Early Seventeenth Century: Some Moments in Marston's The Dutch Courtesan', in Plotting Early Modern London: New Essays on Jacobean City Comedy, ed. Dieter Mehl, Angela Stock, and Anne-Julia Zwierlein (Aldershot, Hampshire, 2004), 98.

2 Visit http://edwardsboys.org/ for a complete history of director Perry Mills's theatrical career making plays with his students and making their work available in performances around the UK, especially Stratford itself and the Globe, and producing DVDs for a worldwide audience. I am fortunate that Mills made the boys' unpublished archive on The Dutch Courtesan available to me, cited later, when introducing the essays that track text into performance, as Edward's Boys Archive. See also Ollie Jones, 'Edward's Boys', Questions and Resources, The Dutch Courtesan, University of York, 2013, http://www.dutchcourtesan.co.uk/edwards-boys/.

3 Scholars usually credit Jean E. Howard, 'Mastering Difference in The Dutch Courtesan', Shakespeare Studies 24 (1996), 105-17, as the first to apply this description.

4 Oxford English Dictionary Online (OED) s.v. 'counterplot', n. 1 - 'plot contrived to defeat another plot' — does not express exactly what I mean here. The play balances the two plots against each other in a kind of contest, more like Samuel Johnson's definition in A Dictionary of the English Language (1755): 'An artifice opposed to an artifice. The wolf here, that had a plot upon the kid, was confounded by a counterplot of the kid's upon the wolf; and such a counterplot it was too, as the wolf, with all his sagacity, was not able to smell out. L'Estrange, Fab. 174' (Lexicons of Early Modern English [LEME]). To some extent, Cocledemoy foils Freevill's success by seizing control as the ironic commentator in act 5 scene 3 and the epilogue. Freevill is unaccountably silent from the middle of that scene to the end, although he remains on stage - a serious dramaturgical and conceptual lacuna. See the essays in this Early Theatre special issue by Michael Cordner, Erin Julian, and Noam Lior. 
5 The Dutch Courtesan was presented by Poculi Ludique Societas (artistic director Linda Phillips) and the Centre for Drama, Theatre, \& Performance Studies, University of Toronto, and organized by Helen Ostovich (dramaturge) and David Klausner (producer), with Noam Lior (director) and Erin Julian (dramaturge), at the Luella Massey Studio Theatre, March 21-24, 2019, with a preview for Renaissance Society of America members on March 19. The symposium, 'Strangers and Aliens in London and Toronto: Sex, Religion, and Xenophobia in John Marston's The Dutch Courtesan', took place 22-3 March, by which time most of the participants had seen the show. This double-barrelled project was supported by a Social Sciences and Humanities Research Council of Canada Connections Grant, as well as by the University of Toronto and McMaster University. The impetus for this project was the in-progress Oxford Works of John Marston, ed. Martin Butler and Matthew Steggle, for which The Dutch Courtesan is being edited by Helen Ostovich and Erin Julian.

6 OED s.v. 'strange', adj. and n. 1-3.

7 The video archive for this 2008 production is available for watching only a trailer on the website, but the DVD for The Dutch Courtesan (and all their productions) is available for purchase at http://edwardsboys.org/shop/.

8 See Performance as Research in Early English Theatre Studies: The Three Ladies of London in Context, McMaster University, 2015, http://threeladiesoflondon.mcmaster.ca/contexts/index.htm for several discussions of the play in relation to early modern topics that have also come up in The Dutch Courtesan.

9 In combining these two words, I am stressing not only Marston's roles for the boys, but also the boys themselves as cheeky and alluring presences on stage, teasing the audience directly and encouraging participation in the comedy.

10 Tisefew's last lines in act 5 scene 2 (condemning women, certainly annoyed with Beatrice and Crispinella for 'talking back') and scene 3 (joking about marriage with his future father-in-law) confirm he is still a flighty urban gallant. On the subject of marriage in this play, I find I have not changed my views since I wrote 'Marriage in The Dutch Courtesan', The Dutch Courtesan, ed. Michael Cordner (2013), https://www.dutchcourtesan.co.uk/marriage-the-dutch-courtesan/, although I have become more suspicious of Tisefew. The spelling of Tisefew comes from Karen Britland's recent edition of the play in the Arden Early Modern Drama series, London, 2018. The essays in this special issue use her text for references.

11 Freevill's last words, directed not to Beatrice but to Malheureux, jeer at his friend's stunned silence: 'Frolic! How is it, sir?' (5.3.64). He echoes Franceschina’s seductive urging of Malheureux earlier, 'Frolic, frolic, sir -' (2.2.64), when he reacts uncomfortably to her singing and dancing. Malheureux's final address to his friend is far 
more sober, weighing Freevill's actions with forgiveness, like Mulligrub's response to those who have come to see him hang — the audience. 